\title{
Pesquisa e a espiritualidade
}

\author{
Alcino Lázaro da Silva* \\ *Emérito, Departamento de Cirurgia, Universidade Federal de Minas \\ Gerais, Brasil
}

Na pesquisa há algumas manifestações, a saber:

- falsificação de resultados

- resultados repetidos

- resultados sem valor

- resultados positivos

- resultados extraordinários

- resultados revolucionários ou que mudam uma era ou um conceito, historicamente considerado imutável.

As cinco primeiras são imanentes, são terrenas, são da espécie humana, desde a mentira até a contribuição que transforma as condutas.

A sexta é transcendente. É a crença. É a fé. Sai do chão, do húmus, do humilde e do homem. É o pesquisador transcendendo, em ordem crescente, talvez, para a metafísica (regras fundamentais do pensamento e o estudo do ser enquanto ser); a teofilosofia ou teofania (manifestação de Deus); o preternatural e finalmente o sobrenatural (divindade).

O que tem a ver este glossário com a pesquisa realizada por nós humanos?

No meu entender de cirurgião, o diferencial do verdadeiro pesquisador, que não se integra ao fatalismo ou ao fundamentalismo, é a transcendência de trabalho, idéias, ideais, espírito de sacrifício e de entrega a uma causa maior, ou seja, a de deixar a marca da qualidade, alçando vôo para além do arco-íris, numa certeza de utopia e ucronia.

O que marca a transcendência, no pesquisador, não é o terreno, os dados colhidos de uma investigação ou a disputa de idéias entre seus pares no plano material e humano, mas sim o propósito de realizá-la mudando-se e mudando também conceitos ou conhecimentos tidos como verdades absolutas.

Como médico atento aos fatos que transformam pessoas e conceitos, posso afirmar que esta reflexão procede porque a pesquisa responsável e verdadeira dá-nos realização pessoal e humanística, ficando como um legado referencial àqueles que vêm depois de nós.

É a tradição. É o repassar traduzindo-se em idéias, esforços, galhardia, trabalho, sonhos, desprendimento do que é terreno e o crescimento para atingirmos um mundo melhor, no imanente que fica, e no transcendente, que se eleva e deixa marcas indeléveis através das gerações que se sucedem e se eternizam no aprender e no transferir com ou sem a nossa presença. 
Não importa como se faz, se o realizamos com a verdade. O que legitima a pesquisa é o que fica, é o que se transforma, é o que se tradicionaliza, é o que se eterniza, é o que se diviniza mesmo na nossa ausência.

Por isto é que a pesquisa há de sempre imperar nas ações, nas intenções, nas traduções de cultura e no permanente daquilo que fazemos bem. Não faz parte do jogo natural dos pares, mas da intervenção de um princípio que supera todas as vontades. É o divino se revelando ao ser humano que realiza, sonha e fica para sempre.

O mundo é recriado todos os dias. A obra da Criação não terminou. Deus precisa das mãos dos homens para continuá-la. Fomos eleitos seus colaboradores queiramos ou não. Sendo assim, todas as pessoas, agnósticas ou crentes, materialistas ou espiritualistas, somos convidadas a ser instrumentos de Deus na evolução e na melhoria do mundo. O que não dizer então, dos pesquisadores quando têm ao seu alcance as condições físicas, materiais e intelectuais para fazê-lo? O que dizer do mundo antes e depois de: Alexander Fleming com a penicilina; o dentista William T.G. Morton e o médico Horace Wells com a anestesia e Ignaz Phillip Semmelweis e Louis Pasteur com a bacteriologia? Independentes da fé que professavam, estes homens transcenderam como pesquisadores e seus trabalhos beneficiaram a humanidade toda.

"Quem salva uma vida salva uma geração inteira e quem mata uma vida mata uma geração inteira".

Concluindo, a pesquisa é imanente e a atitude do pesquisador pode se tornar transcendente se exorbitar-se em espiritualidade orientadora da ontoética que assiste e promove o ser humano. 